\title{
Pro-tests for biomedical research
}

A nimal-rights activists have always had a louder, more public voice than scientists in the debate about animal research, but the tide may be beginning to turn at last. Over the last few years, these protesters, particularly those against primate research, have achieved some key victories. Two years ago, the University of Cambridge canceled its plans to build a new primate neuroscience center, admitting that protests against the facility were a substantial contributor to this decision. The protestors then embraced a new mission- to oppose the construction at Oxford University of a facility to bring all the university's laboratory animals into one building. This center has been under attack by animal rights activists, whose tactics include targeting suppliers and financial investors. For instance, the university had to endure a 16-month delay in construction after a contractor, Walter Lilley \& Co., pulled out in response to bad publicity and dropping share prices.

Proponents of animal testing finally showed some public strength at a rally on 25 February in support of the new Oxford facility. This rally, organized by a group called Pro-Test, was attended by at least 700 people; an opposing demonstration on the same day, organized by the animal-rights group SPEAK (which takes its name from its earlier campaign-Stop Primate Experiments at Cambridge), drew only about 150 supporters.

This development is particularly encouraging for researchers because the demonstration did not consist just of scientists or university officials making a case for animal research. Instead, Pro-Test was formed by a 16-year-old student, Laurie Pycroft, who was disturbed by the one-sidedness of the animal rights debate and started an animal research advocacy website (http://www.pro-test.org.uk/index. $\mathrm{htm}$ ). This grass-roots campaign, which is independent of Oxford University and aims to promote and support scientific research and debate on animal rights, comprises a mixed group of students, Oxford residents and scientists. Many of the group's leaders are not scientists-cofounder Ian Simpson is an economics and politics student who says he was tired of the abuse being hurled at students by animal activists.

There is a legitimate debate to be had on this topic, and animal rights groups have a right to voice their opinions and campaign to change the law. However, the tactics of some of the more extreme groups are much more sophisticated and dangerous. These include targeting people who do not have a stake in the fight, such as suppliers and customers, and vilifying scientists. Contractors have had graffiti painted on their houses and letters accusing them of being pedophiles sent to their neighbors. (The name of the new construction company that is building the Oxford lab is a closely guarded secret; workers wear balaclavas on the job for fear of being attacked.) John Stein, who works on Parkinson disease research in primates, has received death threats to himself and his family and is under police protection. Oxford vision scientist Colin Blakemore has received two letter bombs and has had his car damaged and the windows of his home smashed. These threats have been so effective that many scientists are afraid to speak up in favor of animal research. Even patients who do so are not spared-Parkinson disease patient Mike Robbins, who was brave enough to speak to a partly activist audience about how animal research had helped his life, was met with jeers and told that he should have been prepared to die rather than put monkeys at risk. Pycroft of Pro-Test has also received threats, and SPEAK issued a statement on its website that impugned his character (http://www.speakcampaigns.org.uk/articles/ 20060201wash_hands.php). Pycroft was also recently accorded police security as a result.

Sadly, university officials were conspicuously silent about the Pro-Test march. A week before the event, the Oxford administration emailed students and scientists involved in the march to warn them of the potential hazards of protesting and to tell them that they could still back out if they wanted to. Although the university chancellor, Chris Patten, was spotted in the crowd at the march, he (unlike some faculty members) did not address the rally. And although some of the faculty, such as neuroscientist Tipu Aziz and John Stein, personally spoke out in favor of the rally, the university did not publicly support them. Clearly, this silence is partly motivated by the desire to keep a low profile and not attract more attention from animal activists. However, in doing so, the university missed a golden opportunity to show its support for a rational and balanced debate on animal research and failed to step up and defend its new animal facility.

The rally comes at an optimistic time in the fight for animal research. A US federal jury recently ruled that activists running a web site called Stop Huntington Animal Cruelty were guilty of internet stalking and terrorism and of using their website to incite violence. This organization, like its fellow group SPEAK, posted home addresses and other personal information about animal rights researchers at Huntington Life Sciences, a British company that runs an animal testing facility in New Jersey.

We have always maintained that scientists need to be aware of the tactics of animal rights activists, and that the scientific community needs to find more effective ways to engage the public and counter these attacks. Groups like Pro-Test need to be supported publicly by the scientific community and by university administrations, and we should campaign for tougher regulations on protestors. Meanwhile, Pro-Test says it is planning a larger rally in London. We wish them the best, and we hope that there will be a similar uprising of the law-abiding majority elsewhere.

View more background material on Connotea at http:// connotea.org/user/NatNeurosci/tag/editorial200605. 